Home | Archives | About | Login | Submissions | Notify | Contact | Search

ES Home $>$ Vol. 5, No. $2>$ Art. 25

Copyright (c) 2002 by the author(s). Published here under license by The Resilience Alliance.

The following is the established format for referencing this article:

Lovell, C., A. Mandondo, and P. Moriarty. 2002. The question of scale in integrated natural resource management. Conservation Ecology 5(2): 25. [online] URL: http://www.consecol.org/vol5/iss2/art25/

A version of this article in which text, figures, tables, and appendices are separate files may be found by following this link.

Synthesis, part of Special Feature on Integrated Natural Resource Management

\title{
The Question of Scale in Integrated Natural Resource Management
}

\author{
Chris Lovell ${ }^{1}$, Alois Mandondo, and Patrick Moriarty
}

\section{${ }^{1}$ Centre for Ecology and Hydrology}

- Abstract

- Why Focus on Scale?

- Why Do Scale and Scaling Problems Arise?

- Scale of Investigation: Examples from Africa

- Temporal scale

- Biophysical scale

- Institutional scale

- Scaling-out

- Scaling Down and Scaling Up: Examples from Around the World

- Lessons from integrated catchment management and watershed development

- Lessons from common-property management (group management)

- Lessons from devolution of control for natural resource management

- Reconciling Sector Top-down and Bottom-up Approaches

- Political will

- NGO support

- The right type of initial development project

- What Kind of INRM Research Is Needed?

- Concluding Remarks

- Responses to this Article

- Acknowledgments

- Literature Cited

Lessons from integrated natural resource management (INRM) practiced at different scales are reviewed, with a focus on catchment management. INRM is complex, and many interactions have to be addressed. Consequently, the scale of investigation can restrict the generality and utility of the findings. Examples show that temporal, biophysical, and institutional scales can each be critical. Contexts and dynamics associated with particular scales, and interactions or lateral flows that become important with increasing scale, also pose serious challenges. A conceptual framework is presented for scaling issues in INRM and how to deal with them. To benefit many people over large areas within sensible time frames requires considerable political will, investment, and strategic planning from the outset. Only then will an enabling environment be created to meet a range of preconditions identified in previous studies of integrated catchment management, watershed development, common property management, and devolution. This paper focuses on the links between the organizational/human aspects and the biophysical/technical perspective of various scaling issues. In particular, there is a need to reconcile current top-down and bottom-up approaches, both of which are needed to achieve effective delivery in structured 
programs beyond the scale of a few villages or isolated success stories. Options for bridging this gap are discussed and recommendations are made for research that might be undertaken. Action research is recommended to enable learning-by-doing, and should focus at two levels: strategic studies to help create the political and institutional landscapes required for scaling-up; and specific studies of gaps in knowledge, in particular, programs that account for scale issues. These suggestions are illustrated using the example of groundwater management via nested scales of interdisciplinary research.

KEY WORDS: common property management, community-based natural resource management, devolution, going to scale, integrated catchment management, integrated natural resource management, integrated water resource management, participatory watershed development, scaling-out, scaling-up, spatial scale, temporal scale.

Published: January 2, 2002

\section{WHY FOCUS ON SCALE?}

In many countries, governments and development agencies are turning to integrated natural resource management (INRM) as a means of safeguarding the natural resource base and improving agricultural productivity. In national planning, integrated catchment management and integrated water resource management are now synonymous with "integrated management" of land, water, and forest resources at river catchment scales, typically $5000-500,000 \mathrm{~km}^{2}$. The boundary ascribed in this case is always the physical watershed, or the boundary of the catchment.

In contrast, INRM is also being promoted with community groups and, in some cases, even with individual farmers through community-based natural resource management of common-property, open-access, and privately owned resources in microcatchments, typically only 5-50 km². Social boundaries prevail, and many so-called "watershed development" projects are being undertaken at this scale in developing countries, primarily through nongovernmental organizations (NGOs).

INRM is also central in current thinking on poverty alleviation. The Sustainable Rural Livelihoods Framework (Carney 1998) seeks to improve the lives of poor people and to strengthen the sustainability of their livelihoods. It aims to help people understand and manage the complexity of rural livelihoods through holistic analysis of the five different types of capital asset (natural, manufactured, human, social, and financial), upon which individuals and groups draw to support themselves. INRM is thus being promoted at a very wide range of scales. In all cases, it seeks to address whole agroecosystems, which, by nature, are complex. Thus, many interactions have to be addressed (Campbell et al. 2001).

Gonsalves (2000) define "going to scale" as "bring[ing] more quality benefits to more people over a wider geographical area more quickly, more equitably and more lastingly." If INRM is to go to scale, this raises the thorny question of making trade-offs between these five quality dimensions of capital, because there are many interactions across scales that must be addressed. This paper is prompted by the growing realization that many people, when working across natural scales of space and time, do not always appreciate the full extent of problems associated with scaling, or the implications when interpreting their results. The objective of this paper is, therefore, to highlight some selected conceptual, as well as practical, issues of scales and scaling in INRM, and to present a conceptual framework for dealing with these issues.

As noted by Schulze (2000), scaling in the fields of hydrology and ecology has been comprehensively reviewed in the past five years, through the many contributions to recent special journal issues of, for example, the J ournal of Hydrology, Water Resources Research, Hydrological Sciences J ournal, and Hydrological Processes. It has also been addressed in other publications by Schulze (2000), Harvey (1997), and Jewitt and Gorgens (2000), the recurring contributions by Beven, Wood, Bloschl, and Becker in the peer-reviewed literature, and in recent books edited by Feddes (1995), Kalma and Sivapalan (1995), Stewart et al. (1996), and Sposito (1998). In the fields of economics, environmental sustainability, and organizational development, seminal analyses of scaling have been provided by Schumacher (1973), Adams (1990), Ostrom (1990), Holling (1993), Lee (1993), and Murphree (2000). Drawing on the lessons from these previous analyses where possible, this paper considers scaling issues that arise in INRM , particularly the disjunction between current top-down (predominantly technical) national programs and bottom-up (predominantly social/institutional) community-level projects. Three questions underlie the paper:

1. Under what conditions is INRM likely to be successful and to go to scale?

2. What can be done to increase the probabilities of success?

\section{What kind of INRM research is needed?}

The paper begins by considering why scale and scaling issues arise in INRM. It then presents a conceptual framework for dealing with these issues, using practical examples from around the world to support the logic. The paper concludes with a discussion of the need to reconcile current top-down and bottom-up approaches and the role that research might play in this process. 


\section{WHY DO SCALE AND SCALI NG PROBLEMS ARI SE?}

"Scale" is defined in the Oxford English Dictionary as "relative size or extent." It is a characteristic dimension (or size) in either space or time or both, of an observation or a process, or a model of that process (J ewitt and Gorgens 2000). Intuitively, it is an indication of an order of magnitude rather than a specific value (Schulze 2000).

"Scaling" (up or down), on the other hand, represents the transcending concepts that link processes and actors at different levels in time and space. Scaling, therefore, entails changes in processes and actors, upward or downward, from a given scale of observation. It recognizes the interconnectivity of scales and includes the important constraints, interactions, and feedback (lateral flows) that may be associated with such changes in scale. Included in the concept of scaling are changes in spatial and temporal variability, in patterns of distribution, and in sensitivity (Schulze 2000). Scaling thus goes beyond simple aggregation (up) ("scaling-out," or extrapolation of approaches to sites with similar characteristics) or disaggregation (down) of results at one scale to achieve results at a more desirable scale.

Natural and anthropogenic systems display considerable heterogeneity, which influences the type of processes that dominate and the rates at which they occur. These systems are also hierarchical, with much feedback occurring across overlapping scale spaces (Schulze 2000). Scaling problems related to time, space, institutions, and environments have been addressed by a number of researchers who have proposed various solutions (Table 1). This information can be presented in the form of a conceptual framework or strategy (Fig. 1) to deal with scaling issues in INRM, primarily through very careful problem analysis, coordination of civil and professional science, and iterative learning. The practical examples that follow are provided to support the logic for this conceptual framework.

Table 1. Scaling issues related to time, space, institutions, and environments, and how to deal with them.

\begin{tabular}{ccc}
\hline \hline Scaling problem & Solution & Further reading \\
\hline
\end{tabular}

\section{GENERAL}

Focus on a single scale may obscure important processes that only become obvious at either finer or broader scales.

\section{TEMPORAL}

Change within natural systems occurs at different rates.

Process scales may be episodic (e.g., rainfall), cyclical (e.g., rainy season, long-term rainfall cycle), stochastic with a certain recurrence interval (e.g., a 1-in10-year drought occurrence), ephemeral (e.g., stream flow) or continual (e.g., groundwater movement).

\section{SPATIAL}

Process scales exhibit spatial extent (e.g., the area over which the rainfall occurred), space period (e.g., the area over which a certain rainy season occurs), and correlation space (e.g., the area over which the 1-in-10-year drought left its mark).
Ask questions about cumulative impacts on a broader scale than that being studied. Examine large-scale impacts on a smaller scale.

Analysis should focus on the interactions between the slow and fast phenomena and monitoring should focus on long-term, slow changes in structural variables.

The observation scale at which samples are collected and phenomena are studied should match the scale at which the processes are taking place. Ideally, the process should be observed over a wide extent with high resolution and fine grain to allow any signal within the process to be observed at the appropriate time scale.

As above, match the observation scales to the process scales.
Schulze (2000)

Holling (1993)

\author{
Bloschl and \\ Sivapalan \\ (1995), J ewitt \\ and Gorgens \\ (2000), Schulze \\ (2000)
}

Schulze (2000) 
Dominant processes and physical laws change with scale.

One process may dominate the response (e.g., rainfall distribution may dominate over land use or institutional performance).

Elements in a natural system respond nonlinearly at different rates, according to different threshold scales and lags, and with varying degrees of feedback.

INSTITUTIONAL

The assignment of jurisdiction over particular assets and functions across a spectrum of issues, which may range from local to global.

J urisdictions imply boundaries, which may be spatial or resourcespecific, overlapping or nested in larger systems.

Two contrasting policy thrusts: "big government" (comprehensive authority located at a few nodes across the spectrum of expanding scale requirements) and "small is beautiful" (an approach that seeks to place jurisdictions at local or community levels). solate those significant elements that explain both the signal and the variance in the response. scales at which the processes and physical laws are taking place.

I dentify the dominant spatial forcing function of response and observe over a wide extent with high resolution and fine grain.

Wood and

Lakshmi (1993),

Harvey (1997)

Bugmann (1997), Schulze (2000)

Becker and Braun (1999), van Noordwijk et al. (2001)

Strong local jurisdictions, affected by genuine devolution. Jurisdictions no larger than necessary (at levels where collective problem- solving makes most sense and has most autonomy). Aggregation through negotiated and reciprocal interest and interaction when ecological and functional scale imperatives require larger jurisdictional reach. Jurisdictional size matched to resource base. Constituent accountability. All this takes time and evolution.

Boundaries should be social, with specification of who has responsibility, who has authority, who has appropriative rights, and what the limits of these rights and responsibilities are.

Both are needed. Community-level ownership and decision making are fundamentally important, but community-level decisions should be made within a wider planning Lee (1993), Williams (1998), Murphree (2000)

Lee (1993), Williams (1998), Murphree (2000)

Schumacher (1973), Adams (1990), Lee (1990), Ostrom (1990), framework. The requirement is for Murphree (2000) local regime independence within the context of a larger, scalar interdependence. 
Fig. 1. A conceptual framework or strategy to deal with scaling issues in INRM.

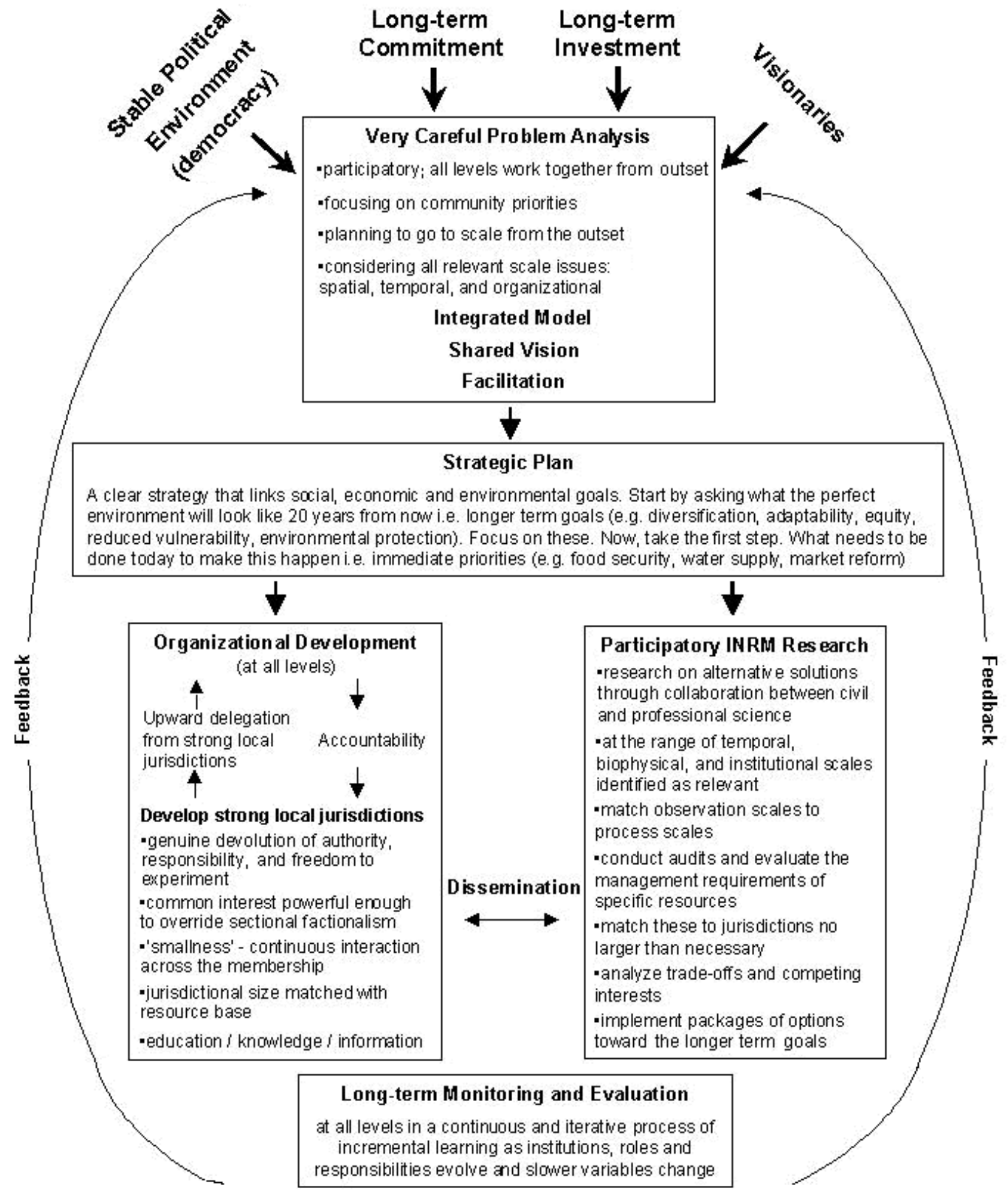

\section{SCALE OF I NVESTI GATI ON: EXAMPLES FROM AFRI CA}


investigation can each be critical and can restrict the generality and utility of findings.

\section{Temporal scale}

Over time, change occurs at different rates (Holling 1993). "Slow change" is cumulative (accumulations of human influences on components of their environment over decades and centuries), whereas "fast change" is a sudden alteration in "fast environmental variables that directly affect the health of people, productivity of natural resources, and vitality of societies."

For several centuries before colonization, the indigenous people of Zimbabwe were part of localized territorial groupings, and natural resources were abundant in relation to population (Beach 1980). However, colonial land apportionment brought an abrupt change in tenure and settlement patterns when these people were forced into native reserves, mostly in parts of the country least favored for agriculture (Moyo et al. 1991). Concentrated settlement was rapid, and related environmental change accumulated over decades, while some environmental legislation put in place over a century ago has survived even to this day (Mandondo 2000 ) because institutions exhibit path dependency and do not easily change (North 1990).

Today, $57 \%$ of people in Zimbabwe live in the "communal lands" designated during the colonial era. All land is owned de jure by the state but, de facto, cropping land is owned by families under customary arrangements. Grazing land, forests, and water are managed through common-property arrangements and are apportioned opportunistically through open access or at the whim of traditional leaders. Environmental concern reaches back to the early 1900s, informed by experiences with disasters elsewhere, e.g., the American Dust Bowl of the 1930s. In 1966, there were reports that $50 \%$ of communal lands were either badly overgrazed or had little herbaceous cover. In the 1980s, a national survey suggested that $>90 \%$ were "severely" deforested, the worst areas being those with the largest livestock and human populations and longest periods of settlement (Whitlow and Campbell 1989). There were also reports of extensive erosion, and many areas began to experience severe water resource problems as groundwater levels fell and water points failed. These observations led to a widespread perception that land management in the communal lands was bringing about general desiccation of the environment.

The Romwe catchment study (Bromley et al. 1999) began in 1992 in Chivi communal land to help resolve the uncertainty. Through a combination of ground-truth measurements, monitoring, and modeling, it partitioned the causes of groundwater decline into rainfall pattern, land-use change, and human abstraction. Rainfall in this region exhibits periods of above- and below-average levels (Chenje and Johnson 1996, Makarau and Jury 1997). This means that areas such as Romwe actually fluctuate between being semiarid and semihumid. The implications for natural resource management are enormous. Village elders recall cattle numbers oscillating in line with departures from mean annual rainfall (Fig. 2; Moriarty 2000). Similar fluctuations may be expected in grain yield, vegetation cover, erosion, and siltation. Modeling catchment hydrology for this period clearly shows that rainfall is by far the greatest determinant of natural resource status. Long-term trends in groundwater levels reflect cumulative rainfall variation, and the main cause of water point failure in the late 1980s and early 1990s was the extended dry period from 1981 to 1992 (Butterworth et al. 1999). Human impact through land-use change is of only secondary importance (Butterworth 1997), and human impact through present groundwater abstraction is trivial (Table 2). The important implication for I NRM is that short projects or "snapshots" are dangerous. In this environment, the temporal scale of investigation must cover (or at least allow projection over) one full cycle of rainfall variability in order to account for natural fluctuations in resource status.

Fig. 2. Cycles of rainfall and cattle numbers in Chivi district, Zimbabwe (adapted from Moriarty 2000). 


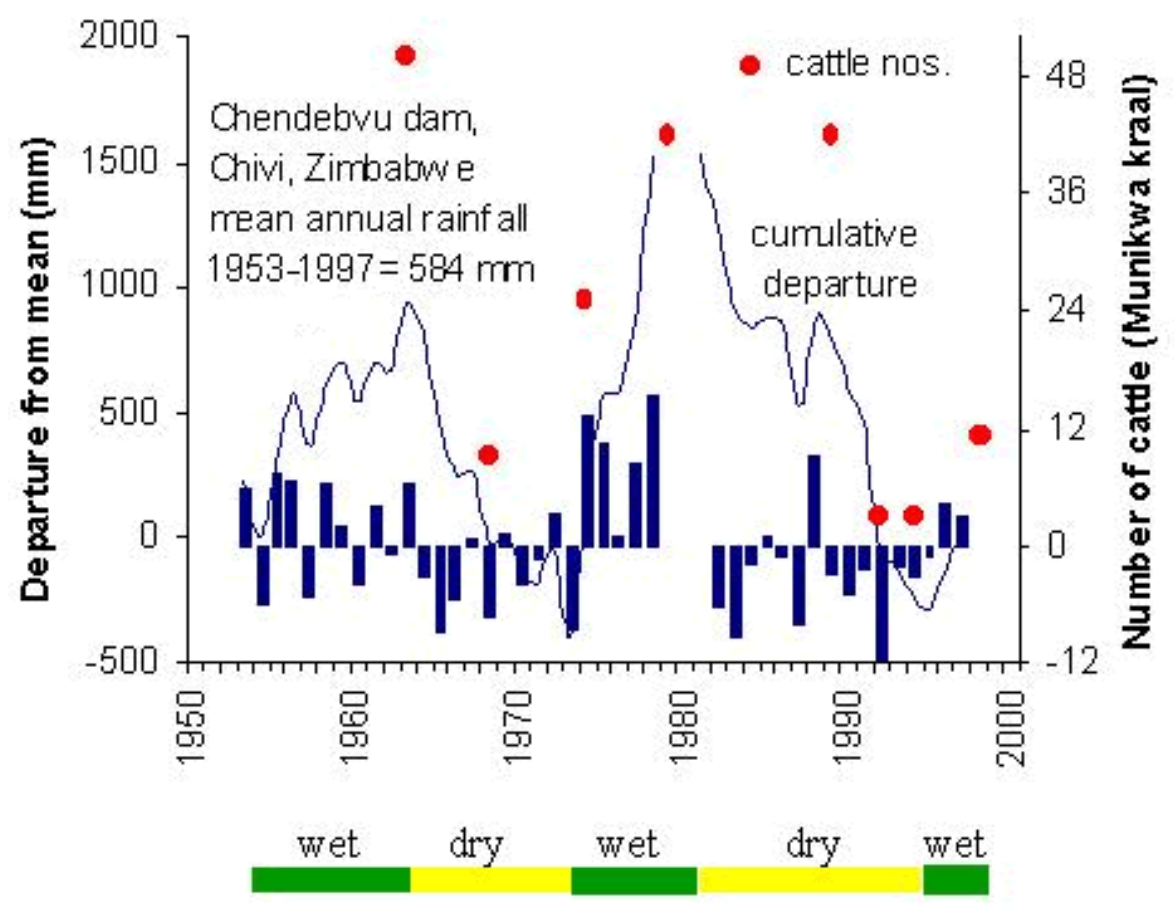

Table 2. The annual water balance of a micro-catchment in southern Zimbabwe (year 1 July-30 June); see Lovell et al. (1998).

\begin{tabular}{lcccccc}
\hline \hline $\begin{array}{l}\text { Annual rainfall } \\
(\mathrm{mm})\end{array}$ & $\begin{array}{c}\text { Run- } \\
\text { off } \\
(\mathrm{mm})\end{array}$ & $\begin{array}{c}\text { Recharge } \\
(\mathrm{mm})\end{array}$ & $\begin{array}{c}\text { Change in } \\
\text { groundwater } \\
\text { storage } \\
(\mathrm{mm})\end{array}$ & $\begin{array}{c}\text { Natural } \\
\text { groundwater } \\
\text { recession } \\
(\mathrm{mm})\end{array}$ & $\begin{array}{c}\text { Human } \\
\text { use } \\
(\mathrm{mm})\end{array}$ & $\begin{array}{c}\text { Balance to } \\
\text { evapo- ration, } \\
\text { change in soil } \\
\text { moisture and } \\
\text { other losses } \\
\text { (mm) }\end{array}$ \\
\hline $\begin{array}{l}1994-1995: \\
738\end{array}$ & 4 & 38 & -34 & 72 & 1 & 695 \\
$\begin{array}{l}1995-1996: \\
990\end{array}$ & 93 & 262 & +100 & 162 & 1 & 634 \\
$1996-1997:$ & 84 & 296 & +62 & 234 & 1 & 556 \\
937 & & & & & & \\
\hline
\end{tabular}

Notes: Maximum values of recharge are calculated as rainfall minus potential evaporation and run-off during the period of groundwater rise, assuming no lateral flow or change in storage in the unsaturated zone. Specific yield $\mathrm{S}_{\mathrm{y}}=0.045$ for the whole catchment, inferred from maximum values of recharge and measured groundwater rise across a network of piezometers. Change in groundwater storage is the annual change in groundwater level multiplied by specific yield. Recession is the difference between recharge and change in groundwater storage. Balance is calculated as rainfall minus run-off, recharge, and human use.

\section{Biophysical scale}

Biophysical scale, as related to groundwater in Romwe, is driven by the crystalline basement geology. In contrast to sedimentary aquifers, where recharge can percolate to great depths and move over large distances underground, basement aquifers are localized in sump points (Fig. 3). Storage takes place only in areas of relatively deep weathering. The aquifers are relatively small in area, shallow, discontinuous, and seldom match the boundaries of surface water catchments. 
Fig. 3. Section through a model of crystalline basement aquifers showing storage of groundwater in localized weathering (Moriarty 2000).

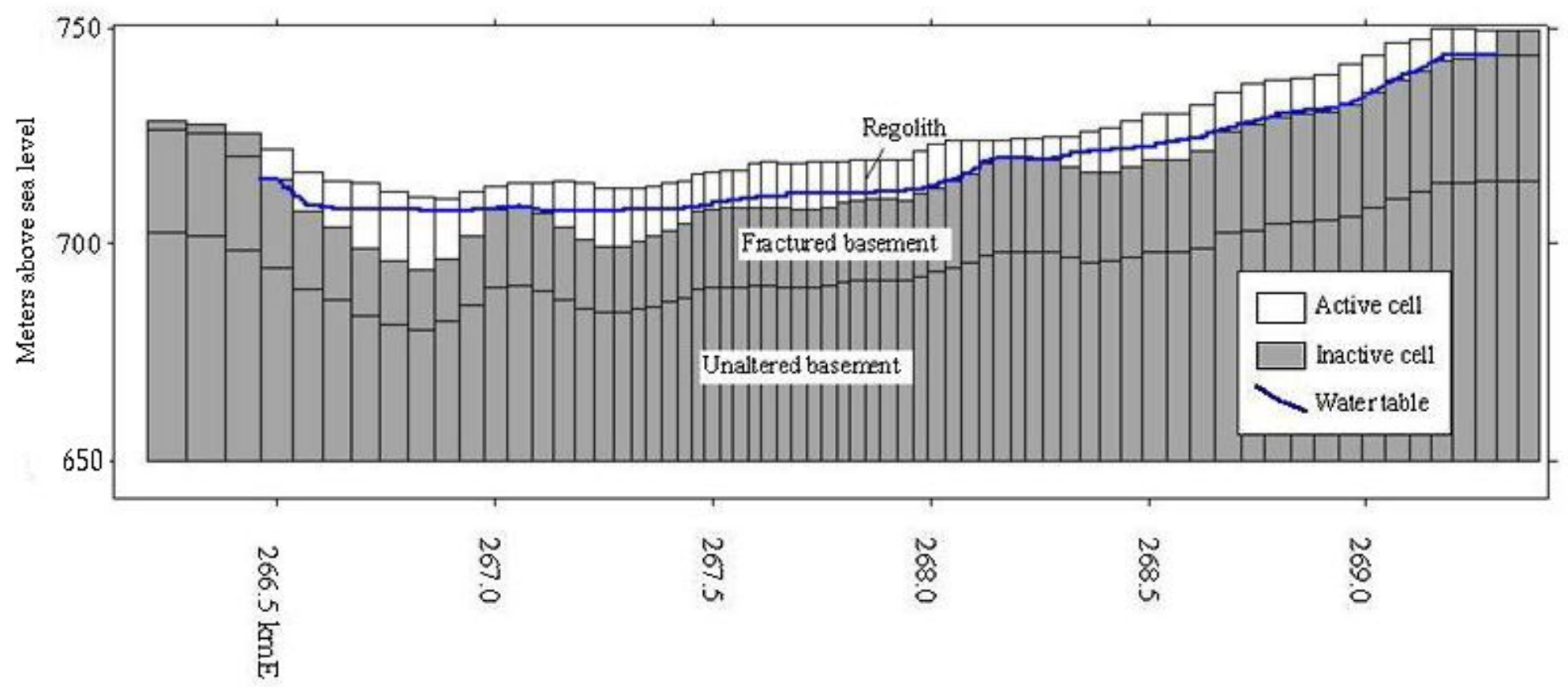

The important implication for INRM in this environment is that groundwater management does not have to be applied consistently over huge areas to have a measurable effect. This contrasts with surface water management, where a beneficial effect may often lie hundreds of kilometers from the point of intervention (e.g., where headwaters are managed to improve reservoir performance downstream). For groundwater in basement areas, decisions and actions that have a real impact on the locally available resource can be made at the local level. Such decisions include whether to adopt water-harvesting methods to enhance groundwater recharge or rain-fed crop production, or whether to develop woodlots on aquifers rather than irrigated gardens. The correct biophysical unit for management in each case is the groundwater micro-catchment. Although this seldom coincides with an existing institutional boundary, it does at least make micro-catchment management an appropriate strategy in this environment, and is a scale conducive to working with small interest groups, typically numbering in the tens of families rather than hundreds.

\section{Institutional scale}

Boundaries are central to INRM because they specify the area over which jurisdictions apply, as well as the roles that particular actors are assigned (Murphree 2000). Specifying jurisdictional zones is, nevertheless, easier said than done, not least because administrative boundaries, infrastructural links, ethnic groups, community limits, and informal networks seldom correspond with physical resource boundaries, to the extent that these can be agreed upon. To complicate matters further, INRM involves the integrated management of a multitude of common-property, open-access, and privately owned resources such as cropland, pastures, forests, and water. Each has an associated complex of often-conflicting interests held by "stakeholders" both inside and outside the particular resource boundary (Nemarundwe 2001).

The choice of institutional scale for INRM conceptually can be made from a continuum of options ranging from "big government" to "small is beautiful" (Murphree 2000). "Big government" is an approach of comprehensive authority located at a few nodes across the spectrum of expanding scale requirements. It arises in response to developing insights about ecological interconnectivity, resource scarcity, and an expanding global economy. It carries with it a strong internal logic; interrelationships of scale are best managed by unitary jurisdiction, or by a few integrated jurisdictions.

"Small is beautiful," on the other hand, is an approach that seeks to place jurisdictions at local or communal levels. Small jurisdictions are more transparent to their constituencies and thus politically acceptable. Controls exerted through local peer pressure are tighter and more efficient than distanced prescriptions on which large jurisdictions have to rely. "Small is beautiful" also carries with it the fact that incentive is the fulcrum for responsibility and the motivation for environmental investments and controls; it requires a clear perception of the links between management inputs and output benefits. Small jurisdictions are better placed to delineate and put into operation these essential linkages. Furthermore, responsibility and authority, which must be linked, can be coordinated under one local institution or explicitly articulated between the limited range of actors involved. 
Small units mitigate the transaction costs of organizing for collective action and are generally associated with mutuality of interest and greater social cohesion arising from easy day-to-day contact. However, the "Small is beautiful" approach can result in a multiplicity of fragmented jurisdictions that lack coordination when it comes to addressing bigger problems of both a local and translocal nature. Such problems that cannot be handled in isolation at localized scales are better addressed by larger, unitary jurisdictions, but these are often directed from a remote center, out of touch with local priorities and aspirations. A question, therefore, is whether those at the top should define small units for INRM on the basis of a subdivision of big units, or whether small units based on local interest groups should build into bigger coordinated units (Appendix 1). In the former, communities usually end up with responsibilities for I NRM without corresponding authority, making it difficult for local institutions to establish areas of jurisdiction in which there are clearly "insiders" with usufruct rights and management obligations and "outsiders" who can be excluded from direct use. In the latter, lack of capacity in lower- and middle-level institutions, and ineffective links between the two, are often key constraints.

I dentifying and negotiating these interests and relationships is a key part of INRM that generally requires external facilitation to advise on organizational development and to help find compromises between potentially conflicting interests (Ravnborg and Ashby 1996). It is inevitable that the solutions, in the form of appropriate institutional arrangements, will be location-specific and resourcespecific to some extent. In terms of direct management, the particular user group and its neighbors should determine the appropriate institutional scale. In terms of program development, this must involve at least the scale at which INRM policy can be decided and enacted. In Zimbabwe, this corresponds to the district council.

\section{Scaling-out}

"Scaling-out" is sometimes used to define spatial extrapolation of successful approaches to other sites with similar circumstances; i. e., replication at the same scale but at different locations. It may involve a certain degree of adaptation, but essentially involves the same type of system boundaries. It depends on identifying sites with similar circumstances, followed by extension. Harrington et al. (2001) provides examples of tools that can help in this process. These include site similarity analysis through GIS, the use of farmer and land type taxonomies, and simulation models. This form of simple area scaling will rarely be appropriate in INRM, however, without detailed institutional investigations in the proposed extension areas, and without asking questions about cumulative impacts on a broader scale than that being replicated. Similar biophysical areas cannot be assumed to have similar institutional arrangements, local culture, or values, and there will be lateral flows of soil, water, air, fire, organisms, people, money, ideas, etc., across the expanding scales.

The examples of temporal, biophysical, and institutional scale issues that we have given, and their associated physical and social contexts and dynamics, highlight that successful approaches will invariably be location-specific and time-specific, to some extent. Rules or relationships that hold at one scale may not transcend scales, and "successful" approaches at one scale may even cause problems downstream. Van Noordwijk et al. (2001) provide the example of plot-scale erosion that leads to considerable lateral flow, impoverishing soil in one place but enriching it in another, with relatively little actually reaching the scale of seas and oceans.

These scale issues, contexts, and dynamics, and the interactions that become important with increasing scale (e.g., through spatial extrapolation) pose serious challenges and explain the nested scales of interdisciplinary research recommended later in this paper.

\section{SCALI NG-DOWN AND SCALI NG-UP: EXAMPLES FROM AROUND THE WORLD}

Experience shows that for INRM to benefit many people across large areas requires considerable political will, investment, and strategic planning from the outset. Success depends primarily on building relationships, in particular, on community participation, which depends on incentive, which in turn is contingent on the creation of an enabling environment to meet a range of preconditions identified in previous studies of integrated catchment management, watershed development, common-property management, and devolution (see, e.g., Gibbs 1986, Ostrom 1990, Shah 1993, UNESCO 1993, Clarke 1994, Ravnborg and Ashby 1996, Farrington and Boyd 1997, Farrington and Lobo 1997, Rhoades 1998, Adams et al. 1999, Murphree 2000; C. H. Batchelor, unpublished manuscript; C. H. Batchelor, J. Cain, F. Farquharson, and J. Roberts, unpublished manuscript). These preconditions or lessons (see Fig. 4 ) will be discussed in more detail. 
Fig. 4. Some generalized lessons or preconditions for successful INRM.

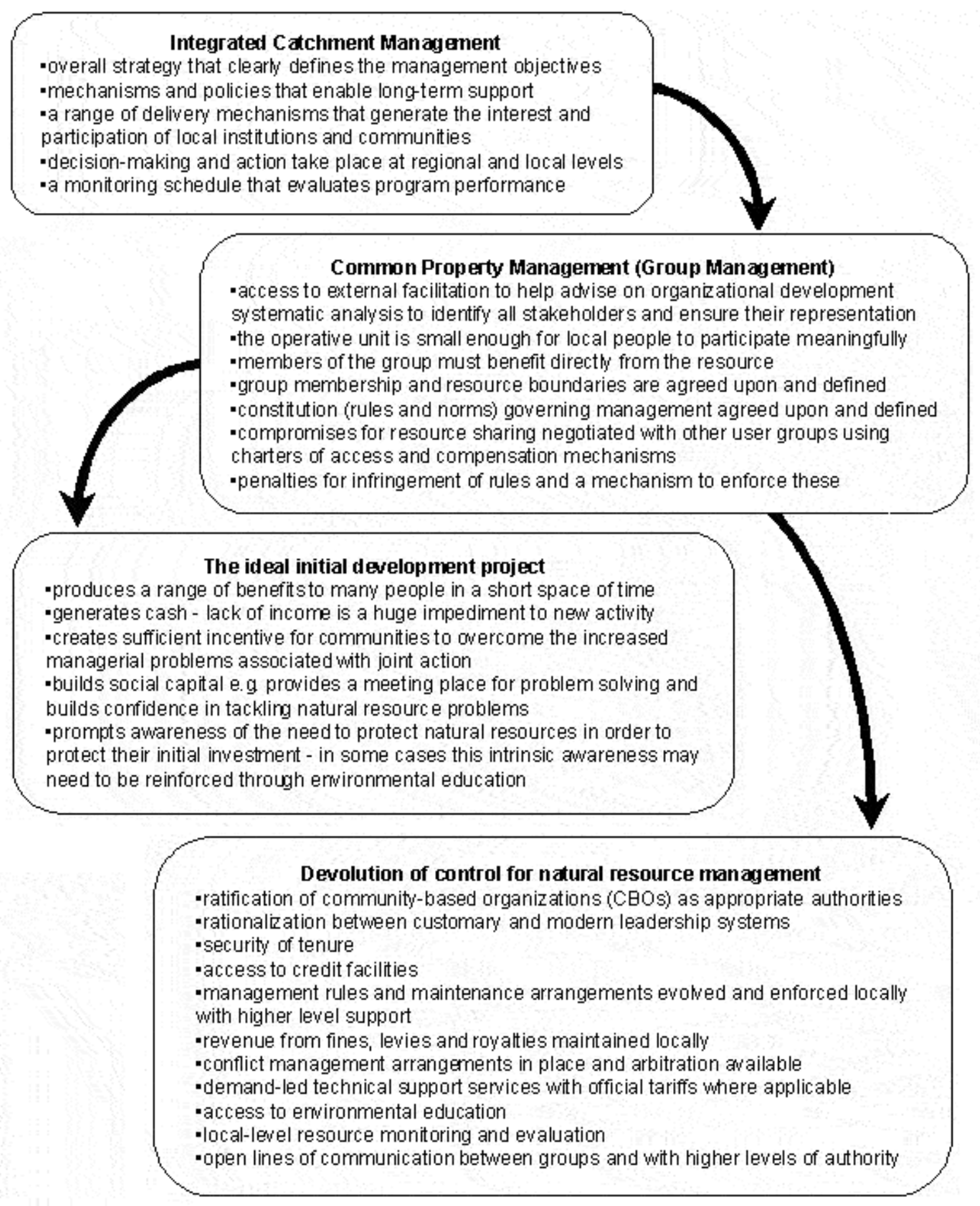

\section{Lessons from integrated catchment management and watershed development}

Following the United Nations Conference for the Environment and Development (UNCED) held in Rio de Janeiro in 1992, most nations subscribed to new principles for the integrated management of land, water, and forests. Although program names vary from nation to nation, all express similar aims. It should be noted, however, that despite considerable interest and effort, these national programs have rarely delivered. The main reasons appear to be the top-down sector approach taken, a lack of community involvement in the process, and a lack of appropriate delivery mechanisms at ground level to generate the interest of local institutions and communities. Indeed, the lack of appropriate delivery mechanisms was identified as the main failing with first attempts to implement integrated catchment management in both Australia and South Africa (Blackmore 1995, van Zyl 1995). The importance of community participation and local development to the success of these national programs cannot be overstated. 
In contrast, a recent survey of community-level watershed development projects considered the impact of taking a fully participatory approach (Hinchcliffe et al. 1999):

Contrary to common viewpoints, the catchment ... is not always the most rational unit for all activities... Because neither catchments nor the groups who live among them are homogenous, the nature of their problems and the possible solutions are varied and complex. Prescriptive external solutions have little chance of fitting ... and may be inappropriate or unacceptable to the majority of farmers. Nevertheless, working with common interest groups on contiguous areas of land, whose boundaries may be administrative, social or physical, enables agency staff to provide assistance more efficiently than where individual farms are scattered ... Thus it is not "catchment management" as such that results in improvements in agriculture and livelihoods. Insistence on such a framework may run contrary to communities' needs and priorities... Rather it is the integration of improved husbandry of land, of crops and of livestock with better interpersonal relations in the context of catchments that produces tangible benefits.

Twenty-three case studies, ranging from Landcare in Australia to the Aga Khan Rural Support Program in India, present a rich and complex picture of the problems, achievements, and continuing challenges faced by conservation professionals and farmers around the world. The features common to successful projects at this community level include:

- Small micro-catchments with boundaries rarely defined and rarely hydrological.

- Planning units that are collective, i.e., a community-based organization ( $\mathrm{CBO}$ ) rather than individual farmers, with the emphasis on working with people who have something important in common (e.g., caste, blood, class, common dependence, common priority).

- A reasonable degree of social organization through which the necessary critical mass of collective action can be organized. Where this does not exist, it has to be created, requiring significant development of trust and platform building. The social units most appropriate for participation need to be tailored to the particular setting, and the approach may not work where "community" is not the norm and people are devoted to individual actions (e.g., tribals, absentee landlords, landless people).

- Flexibility. A thoroughly predesigned and preplanned project is not considered a good project. Indicators of success focus on adaptation rather than adoption.

- Clearly defined roles for the different organizations: state departments, NGOs, and CBOs.

- Emphasis on introducing government personnel to participatory farmer-to-farmer extension and on reorienting initial projects and extension approaches away from "treatment" of specific problems toward whole-catchment management focused on livelihood priorities.

- Tangible benefits to participants in a short space of time.

- Group access to finance through credit or other means.

- Highly subsidized by government and donors, with local residents contributing only a small percentage of the value of the development works in cash or as labor. Adequate financial and institutional support is considered critical where authorities are handing responsibility for complex, costly, and conflict-ridden problems back to local people.

Almost without exception, however, these NGO-led projects are small in scale and can be expanded only by repeating the same slow, costly, in-depth techniques in successive villages. Farrington and Boyd (1997) identify three features important to achieve more expeditious replication over wide areas:

- Community participation in local development. This generates a stake in the process and enhances the prospects of effective and sustainable joint action. However, entirely "bottom-up" proposals for improvements limited to the possibilities already known to rural people will not suffice. The process must be open to the wider possibilities known to outsiders and in a format for planning, implementing, and monitoring that allows these outside agencies to verify that public funds have been spent properly.

- Support agency roles that allow the necessary degree of participation for interventions to be planned and function adequately, but that at the same time are rapidly replicated. A criticism of World Bank-supported watershed development, for example, is that despite large amounts of funding on infrastructure, institutional arrangements are rarely adequate to continue maintenance. On the other hand, long-term empowering approaches adopted by some NGOs achieve institutional sustainability in individual villages at the cost of extremely slow replication. A balance is required.

- A clear strategy for scaling-up. Expansion pathways for NGOs are often poorly defined.

Farrington and Boyd (1997) conclude that joint action and participation are central to successful management of natural resources. Replication at any scale larger than a few villages has to occur within a structured program and has to be based on multi-agency partnerships. An alternative to the slow, long-term empowering approach does not emerge from NGOs, meaning that the public 
sector must undertake exercises in consensus and program building.

In only one setting, the Indo-German Watershed Development Program (IGWDP) in Maharashtra state, India, did Farrington and Boyd (1997) find these preconditions clearly defined at the program design phase (Appendix 2). Farrington and Lobo (1997) discuss the institutional arrangements that have ensured the involvement of all stakeholders. They conclude that the program has generated a technically sound, but at the same time participatory, watershed planning methodology, a coherent transition from capacity-building to full-scale implementation, and a practical framework for field-level collaboration among state departments, NGOs, and CBOs.

Improvements in production form only part of the IGWDP vision. In many respects, a more important part is the strengthening of local people's capacity to draw on civil society. I NRM involves essentially political questions within and between villages and with various levels of the administration. Progress cannot be made through local-level resources alone. Government provides technical support services and also much of the fabric necessary, in the form of legal and administrative systems. Local organizations must be able to engage with government in order to draw on these services and systems in ways that meet their needs.

\title{
Lessons from common-property management (group management)
}

Common-property management must be linked to human welfare as the major motivating force. The basic social requirement for achieving this is that the operative unit, the producer/user community, should be small enough for households to participate meaningfully. The question of scale is critical for community cohesion (Murphree 2000). The smallest social organization above the household-the village community-should be able to meet regularly to decide management issues, as was customary in traditional open governance. If a community is too large or too dispersed for free discourse between members, it is preferable that it divides into smaller entities, each of which is then represented by a coordinating body. The economic requirement is that the producer/user community must benefit from its labor through the sale of produce. This economic incentive provides the most important rationale for managing the resource. The institutional requirements are security of tenure for specific user groups, and regulations that evolve and are enforced locally.

\section{Lessons from devolution of control for natural resource management}

Williams (1998) and Murphree (2000) discuss the emerging problems of sustainable resource management. Essentially, the challenge is to devise governance arrangements that are supportive of the diverse needs of a variety of users, yet protective of the long-term productive capacity of these resources. The requirement is for local regime independence within the context of a larger, scalar interdependence. New and effective institutional arrangements are needed. A growing recognition of this need is evident. In most countries, state property regimes, in which government officials exercise exclusive decision-making powers, are being de-emphasized in favor of decentralized and participatory management of natural resources. The specific approach used to encourage active local participation varies from one country to another. In some, it has taken the form of legislative reform of land tenure and natural resource management policy conducted over time. In others, land-use planning based on "village territories" has become popular. In all cases, governments have sought to clarify tenure issues and to reinforce the rights of local communities to mange their resources through granting legal recognition and decision-making authority.

\section{RECONCI LI NG SECTOR TOP-DOWN AND BOTTOM-UP APPROACHES}

\author{
Van Zyl (1995) emphasizes that INRM must be people centered, but also states that:
}

To succeed in managing...managers must be in a position to see the whole picture, understand the resources, the customers, their needs and aspirations and to make wise decisions in the interests of all. This requires a holistic approach to management that integrates skills in engineering, economics, politics, social and environmental management. It involves the bringing together of various disciplines and the compilation and development of multidisciplinary teams of champions. Due to the ....site-specific nature of (water) resources in terms of physical properties, land use and people involved, it is not feasible to manage ... on a national basis without basing it on logical management units. Because we are dealing with a natural resource, driven by the hydrological cycle, it makes good sense to use river catchments as such units.

This is INRM as viewed from the top. Although this approach has many benefits, the crucial elements missing are local ownership and the incentive to undertake any INRM strategies that might be developed as part of this top-down approach. An alternative view is from the bottom, whereby INRM is seen as a means of scaling-up community-based schemes to the regional or catchment scale. This approach has advantages in terms of achieving local ownership of the process, but it has disadvantages with regard to structure, regulation, and equity. For example, communities developing projects in headwater catchments are unlikely to put a high priority on ensuring that the resources of downstream users are not adversely affected.

The key issue that emerges is the need to effectively link community-based projects within larger, structured programs. Both are essential, but they must be implemented in a package that meets in the middle (Fig. 5). INRM needs to occur through a structured program that provides overall planning, coordination, and long-term financial support for activities at regional or catchment level. Equally it needs to occur at the scale of the common interest groups on contiguous areas of land whose boundaries may be administrative, social, or physical. At this level, the essential features are the common interest group, the development process that facilitates participation in joint action, and the structured program. The lack of overlap between different physical areas and social 

planning for downstream effects.

Fig. 5. In search of INRM.

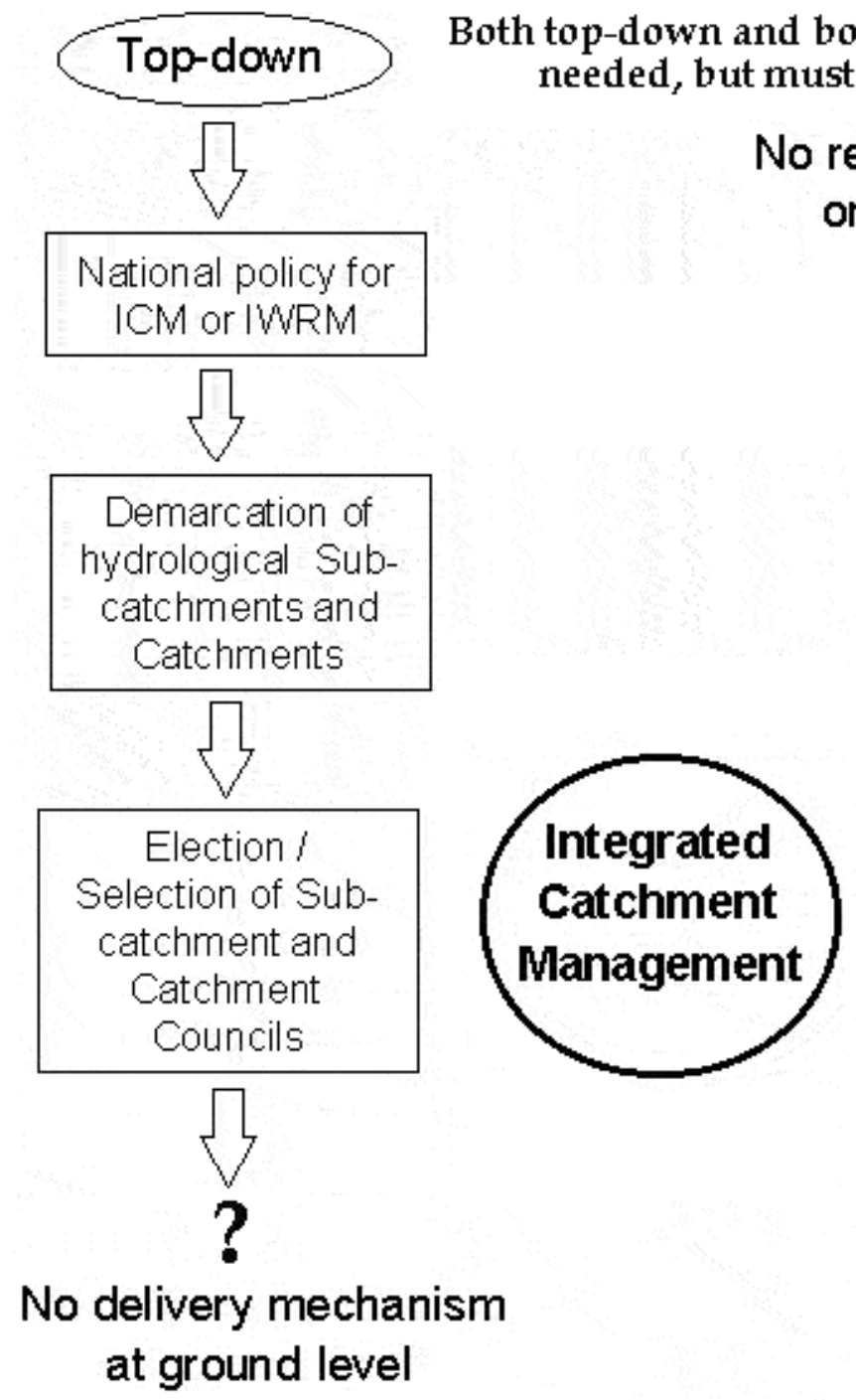

Both top-down and bottom-up approaches are

No replication mechanism or regional planning

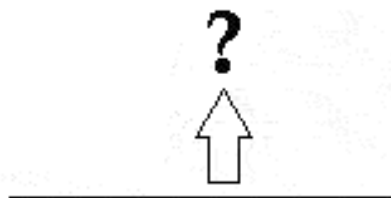

Successful "pilots"
in restricted areas

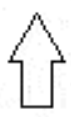

Investment and

development in

individual

communities

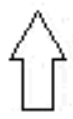

Usually an NGO

or CBO initiative

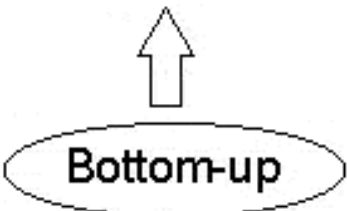

\section{Political will}

Bottrall (1992) discusses the dichotomy of simultaneously ensuring both "local ownership" and equitable distribution and regulation of resources at the larger scale. He makes the point that government departments address issues on a fragmented sector basis, and their attempts to promote INRM tend to have high administrative costs (e.g., interdepartmental committees or new multisector units). By contrast, communities find it relatively easy to think and act holistically. The administrative costs of INRM will be kept within acceptable limits only by devolving significant management responsibility to CBOs and, wherever possible, NGO intermediaries. The challenge is to effectively link government departments with each other and with local-level organizations. Interdepartmental committees are a poor attempt, and falter where they are not properly supported by resources specifically allocated by each department.

Government allocations to holistic INRM programs instead of to conventional departmental top-ups would help to facilitate the necessary cross-sector interfacing. The problems of cross-sector/interministerial collaboration should also be easier to overcome through properly established decentralization. However, this requires adequate capacity, especially at lower and middle levels, and genuine social empowerment through devolution of authority, responsibility, and freedom to experiment (Murphree 2000). Authority and responsibility for management must be vested together at the lowest appropriate level and only delegated upward where 
absolutely necessary. Each level must be functioning properly, and a missing level is essentially a block. Parachuting to community level, for example, as many external NGOs do, will not help INRM go to scale.

Decentralization is thus a precondition for scaling-up, but equally, too much decentralization disperses authority and, simultaneously, any control over forms of authority. Assigning increased authority and responsibility to local users without ascertaining the range of functions of a resource, the diversity of interests among users, and the capability of local institutions to take on these roles, will complicate rather than solve the problems (Williams 1998). Governance arrangements for INRM must be an appropriate mix of local and state institutions. The rights of individuals within legal entities are contractual arrangements that do little to secure property rights in the absence of demarcation, registration, and records, all of which require an institutional framework located in and managed by the state. Local institutions have a comparative advantage in dealing with resource use and preservation issues at community level, but they vary widely in their organizational and management capabilities. State institutions are needed to provide support for the formation or strengthening of these local institutions where they are non-existent or weak. Given the wide variety of users and the complex set of overlapping rights that are continuously contested, the need for conflict mediation will be fairly constant. State institutions will be important in resolving disputes and providing an appropriate legal framework to support and enforce resource use agreements worked out by the different local groups (Ostrom 1990, 1995).

\section{NGO support}

The NGO perception of scaling-up recognizes that it is about relationship-building. It is not just replication of technologies or approaches, but expansion of principles and knowledge, such that people build capacity to make better decisions and influence decision-making authorities (Gonsalves 2000). In this respect, scaling-up has power and development dimensions. However, the "learning-process" approach that is adopted generally proceeds through three slow stages: learning to be effective (with emphasis on building interpersonal relationships); learning to be efficient (withdrawal from individual sites); and learning to expand (but focused on local organizational development rather than broader policy and institutional arrangements). The NGO approach tends to be: try a project, have success, then think about scaling-up, including development of relations with the state and how to sustain the momentum, both vertically across institutional levels and horizontally. As we have seen, for local success to go to scale, collaborative planning from the outset between communities, NGOs, and the state is crucial if social change and empowerment of people is to occur in a meaningful and lasting way. The state and NGOs will need to undertake certain commitments to help reconcile current top-down (predominantly technical) and bottom-up (predominantly social/institutional) approaches to INRM (Table 3).

Table 3. Undertakings by government and NGOs to help bridge the gap between top-down and bottom-up approaches to INRM (adapted from Gonsalves 2000).

On the part of governments

Provide a stable, supportive, and enabling environment and a political culture that allows democratic elections and rule of law.

\section{Provide long-term meaningful support to INRM.}

Implement meaningful devolution of control with institutional capacitybuilding at middle and lower levels.

Avoid top-down community manipulation and NGO tension by ensuring that programs are led by, and remain focused on, community priorities.

Provide clear mandates that allow NGOs to participate.

Provide clear mandates among state agencies.

Develop infrastructure for disadvantaged communities.
On the part of NGOs

Forge strategic alliances to generate impact on a large scale.

Build up sufficient broad-based community pressure to influence policy.

Lobby politicians; invite them to see what is happening in the field and how this fits with their own mandates.

Influence market forces and market development.

Encourage local champions.

Help to construct a shared vision for scaling-up through active participation by all.

Strengthen community knowledge and skills in law, planning, decision making, marketing, team building, communication, conflict resolution, and natural resource management, 
Provide appropriate technical support.

Ensure independent monitoring and evaluation and documentation of lessons learned and best practice.
Strengthen community

understanding of the government

system in the scaling-up process.

Build social capital (trust/cooperation networks).

\section{The right type of initial development project}

Delivery mechanisms now being used with relative success in Australia and India involve financial incentives (Farrington and Lobo 1997, Campbell and Woodhill 1999), but few developing countries have the same financial resources or political will as Australia and India. Kerr et al. (1996) also believe that alternatives to subsidies should be sought in most instances. For developing countries, approaches to INRM are needed that are appropriate to the political setting and that are considerably cheaper. Linking I NRM to rural development is one option. However, certain types of development will be more effective than others (Fig. 4). The ideal initial project will satisfy the three basic requirements (social, economic, and institutional) of common-property management. It will focus on a resource of immediate concern to the local people, and one that has the potential to generate meaningful income. It will increase social capital by promoting collective responsibility. It also will build community confidence and institutional structures that will help to address other natural resource problems.

Rural water supply is an example of an ideal project for dryland areas. It is already central to development in these areas, already attracts donor funds, and, in many countries, it already brings together different ministries in an established institutional structure. These are all-important ingredients in scaling-up. The social, economic, and institutional criteria can then be met by developing productive water points (Waughray et al. 1998, Lovell 2000). Unlike conventional water points, these are designed and implemented to provide sufficient water for income-generating projects as well as domestic use. They are public water points, and are implemented in a manner that empowers the local group to own the resource and assume authority and responsibility for its management. Income from production creates the incentive for this management and meets the operation and maintenance costs. In the longer term, reinvestment of this income and the experience of successful collective action create wider benefits to the local economy and the environment through diversification of livelihood strategies and intensification of the farming system.

\section{WHAT KI ND OF I NRM RESEARCH I S NEEDED?}

When considering the contribution that research can make to INRM, one must recognize that the concept itself is a research product, emerging from a series of studies investigating different development paradigms. It has emerged as a model for a universally applicable means of safeguarding the natural resource base and improving productivity. With the wisdom of hindsight, few involved would now question this need for holism.

An important task for I NRM research, therefore, is to test and subsequently transform the hypothesis into proven principles that can, with confidence, be applied in practice. The research effort should focus on bringing the INRM approach into operation and on generating understanding by observation. This requires action-research to learn-by-doing within applied INRM programs. The research should address major resource management problems in an ecoregional context. In order to address scaling issues, studies in each thematic program should focus at two levels:

1. Strategic studies that increase knowledge of the preconditions for scaling-up and contribute directly to policy formulation and institutional development. These will concentrate on improved planning, helping to ensure that governments create the enabling environment required to cope with the demands of applying INRM (e.g., piloting genuine devolution where this is not yet enacted).

2. Specific interdisciplinary studies at nested scales that investigate key constraints or gaps in knowledge. These will concentrate on the interconnectivity between scales and on separating and evaluating the influence of factors that are natural and beyond the scope of management (e.g., rainfall variability); reversible by changing local practices (e.g., land management); and external, in that they can only be changed by alterations in policy and institutional arrangements (e.g., legislation, incentives, power relations, resource tenure, civic education).

Table 4 illustrates these suggestions with an example of groundwater management. The process starts with real problems, and how the big issues interact with local situations. These interactions need careful analysis so that the concept of the system is clear before participants embark on small-scale, community initiatives with naïve expectations about later scaling-up. How, and to what extent, do local problems perceived by resource users relate to global (external) issues? What might need to change at the global level to achieve large-scale, long-term success? How will activities at the local level actually contribute to this? In many cases, the required temporal, spatial, and institutional scales of study will be wide ranging. 
Table 4. An example of nested scales of interdisciplinary research to address scaling issues.

Problem Analysis: Groundwater decline is a key degradation issue in the 21st century. Aquifer levels have fallen in recent decades in several major grain-producing regions of the world. This decline is popularly attributed to groundwater mining. However, significant gaps in knowledge and understanding of the processes of groundwater decline remain, and limit our identification and implementation of appropriate management actions. This thematic research program will systematically address the issue of groundwater decline in the ecoregions represented by the Punjab of India and the North China Plain.

\begin{tabular}{ccc}
\hline \hline & \multicolumn{2}{c}{ Scales of investigation } \\
\cline { 2 - 3 } Examples & Spatial/Institutional & $\begin{array}{c}\text { Temporal } \\
\text { (projection in } \\
\text { some cases) }\end{array}$ \\
\hline
\end{tabular}

\section{STRATEGIC STUDIES}

Pilot devolution of control for natural resource management, e.g., through environmental education, capacitybuilding, village government.

Promote collective responsibility for groundwater through programs that support group-based activities and discourage private exploitation.

With user groups, NGOs, and government, apply knowledge gained in the related specific studies to develop and field-test appropriate technical, legal, financial, and institutional incentives for effective management.

Independent monitoring and evaluation.

\section{SPECIFIC STUDIES}

Model the importance of spatial and temporal variability of rainfall and land management to the reported groundwater decline.

Partition the decline to natural recession and human use, and partition the natural recession to deep flow, lateral flow and vegetation water use.

Simulate the impacts of increasing population and changes in land use and climate.

Cost-benefit analysis of potential macroeconomic interventions, e.g., import grain from water-rich areas to reduce need for local production.

user group; $\quad$ years
village; ward;

council; ministerial

water supply $\quad$ years
sector

user group; years

village; ward;

council; ministerial

as above years; decades

field, aquifer, wet year, micro-catchment, average year, dry river catchment year, "20" year cycle of variability

field, aquifer, micro-catchment, year river catchment

\begin{abstract}
user group; village; ward; council; field; aquifer; microcatchment; river catchment
\end{abstract}

regional; 'global' wet year, average year, dry year, "20" year cycle of variability

years; decades 
NRRD (1998) notes that such different categories of research, and the several relevant disciplines needed for comprehensive understanding, will require effective coordination and management. The integration of relevant strategic knowledge from existing sector programs will also be important, as will creation of reliable and enduring partnerships between researchers in different disciplines and between institutions representing different stakeholders, particularly those who will use the knowledge directly.

Although experimentation with scaling-up, community-based approaches that engage multiple stakeholders has continued to grow, much of the experience has not yet been well documented. Long-term monitoring and evaluation will be important for comparative analysis to enable policy makers to synthesize lessons learned and identify principles that can be applied across multiple sites. Education of farmers will also be key. Local resource users generally possess inadequate scientific knowledge to complement their own indigenous knowledge (Williams 1998). A weakness of participatory projects to date has been the lack of scientific rigor in appraising impact. Many projects, from Africa to India, proudly attribute indicators of improved management, such as an increase in grain yield or a rise in groundwater level, to some desired change in social or human capital, such as enhanced sense of community responsibility or improved traditional soil and water conservation. However, they fail to acknowledge the complexity of the natural system or to account for important external factors. I NRM research has an important role to play in this regard, in both interpreting and supplying information. The timely availability of appropriate information about the interrelationship between different resources is critical for meaningful participation and decision making by local organizations.

\section{CONCLUDI NG REMARKS}

A lesson to date in INRM is that there are no magic, generic solutions and no quick fixes. To benefit many people across large areas requires considerable political will, investment, and planning from the outset. It also takes time, as institutions, roles, and responsibilities evolve and the slower variables change. Emphasis needs to be on long-term management of resources at all levels, even though this may not be attractive to bureaucrats and politicians who want another glittering initiative (Batchelor et al. 2000).

The process also goes far beyond simple, area-based extension or expansion concepts envisaged by some NGOs. There must be demand for INRM at the local level, it should be integrated with means of enhancing livelihoods, and it needs to be tailored to local conditions. Nevertheless, account must be taken of the "global" as well as the site-specific causes of the problems facing people and the environment (Turton and Farrington 1998).

Within individual scientific disciplines, the expertise exists to deal with these scaling issues. In the development community as a whole, there is also experience of the considerable challenges posed by integrated natural resource management. In this paper, five themes emerge as principles in the search for a strategy that will help to ensure that integrated natural resource management can be achieved successfully at scale:

- the political will to democratize and genuinely empower local communities;

- shared visions across all institutional levels, based on careful problem analyses;

- effective coordination of civil and professional science;

- commitment to a continuous and iterative learning process; and

- long-term (10-20 year) funding for research in tandem with organizational development.

These components raise important questions about how to create the necessary political will, how to facilitate shared visions across all institutional levels, and who should set research agendas. However, without these components, current top-down (predominantly technical) approaches to integrated natural resource management, and bottom-up (predominantly social/institutional) approaches, will remain de-linked, and we will continue with the ineffectual structures and stratagems of "big government" and the well-meaning, but piecemeal, attempts of "non-government."

\section{RESPONSES TO THIS ARTI CLE}

Responses to this article are invited. If accepted for publication, your response will be hyperlinked to the article. To submit a comment, follow this link. To read comments already accepted, follow this link. 


\section{Acknowledgments:}

This publication is an output from a project funded by the UK Department for International Development (DFID) for the benefit of developing countries. The views expressed are not necessarily those of DFID. We acknowledge the helpful inputs and comments of J eremy Cain, Bruce Campbell, Pete Frost, Isiah Mharapara, J eff Sayer, Steve Twomlow, and four anonymous reviewers.

\section{Appendix 1. The CAMPFI RE Program, Zimbabwe}

Although Zimbabwe's natural resource governance structures and processes have for quite some time been "big-government" typesectorally insular and overcentralized-recent reforms have created hierarchies that appear to address the scale problem. The country's flagship in participatory natural resource management is the Communal Areas Management Program for Indigenous Resources (CAMPFIRE), in which communities are empowered to manage wildlife and benefit from it. The program is based on the concept of the "producer community" as the basic unit of social organization through which communities can be empowered to manage local resources. The original idea was to focus on units at the subdistrict level as the producer communities (R. B. Martin, unpublished report) but, in terms of institutional scale, the program has been variously implemented at the levels of village development committees (VIDCOs), ward development committees (WADCOs), traditional villages, and even entire districts. VIDCOs and WADCOs are structures created under the Prime Minister's directive of 1984, purportedly to give a democratic orientation in the process of planning for local development. However, they are demographically defined administrative units superimposed on traditional villages with which they do not correspond in terms of boundaries, membership, or roles. Although these units have each variously been assumed to represent "community," the "communities" in which the local people have had a major stake in defining themselves and their roles and responsibilities have generally been associated with greater success, particularly where relatively small (Peterson 1991).

\section{Appendix 2. \\ Preconditions for scaling-up, defined in the design phase, in the Indo-German Watershed Development Program, India}

1. The setting of appropriate criteria for the selection of watersheds, villages, and local-level NGO partners, and the design of locallevel collaborative mechanisms

Technical criteria include: notable erosion, land degradation or water scarcity problems; villages located in the upper part of drainage systems; watershed size around $10 \mathrm{~km}^{2}$; village boundaries corresponding closely with those of the watershed. Socioeconomic criteria include: villages poorer than average; no wide disparities in size of landholding; villages having shown a concern for resource conservation and having a known history of coming together for common causes. As a condition for support, villagers must commit themselves to banning the felling of trees; banning free grazing; undertaking social fencing to protect vegetation; reducing excess populations of livestock; limiting water-intensive crops; contributing voluntary labor to a value of $16 \%$ of the unskilled labor costs of the project (landless and single-parent households exempt); starting a maintenance fund; setting up a village watershed committee. In the interests of replication, the IGWDP decided not to work with larger NGOs inclined toward long-term, empowerment-type approaches to group formation.

2. The design of village-level mechanisms for participatory planning, learning, and implementation

Planning by agencies based on external maps failed. The approach subsequently developed relies on consultations with farmers in their own fields, i.e., community mapping, in partnership with external support agencies such as the Forestry Commission. A capacitybuilding phase of up to one year is undertaken in which a small segment of the watershed (typically 100 ha) is rehabilitated. Funds for this phase (up to US $\$ 16,000$ ) are provided by the IGWDP through its technical-support NGO.

3. Design of a sustainable mechanism for screening and funding individual proposals submitted for watershed rehabilitation

The IGWDP has created mechanisms that channel funds to local organizations with as few intermediate steps as possible. It has established a project-sanctioning committee headed by the National Bank for Agricultural and Rural Development. The central role played by this respected national organization in assessing and channeling finance to donor-supported projects is a cornerstone of replicability. Also, local currency can be channeled through this mechanism once foreign funds have dried up. 
The IGWDP has focused on obtaining political support, first by inviting members of the Legislative Assembly to visit successfully rehabilitated pilot watersheds, then to obtain a Cabinet resolution implementing this devolution of control to village level through joint forest management arrangements in the state.

5. Establishment of channels for drawing on technical expertise in the post-rehabilitation period

The demand from communities for information and assistance to build on their initial success and to start a range of new projects is facilitated in the IGWDP by a watershed organization trust (WOT). This is a body of 29 staff, covering a wide range of social and physical subjects, who help to put NGOs and CBOs in touch with relevant state departments. These links and the go-between role of the WOT are vital.

\section{TERATURE CITED}

Adams, W. 1990. Green development: environment and sustainability in the third world. Routledge, London, UK.

Adams, M., S. Sibanda, and S. Turner. 1999. Land tenure reform and rural livelihoods in Southern Africa. Natural Resource Perspectives Number 39. ODI (Overseas Development Institute), London, UK.

Batchelor, C. H., M. Rama Mohan Rao, and K. Mukherjee. 2000. Watershed development-or should it be watershed management? Case study 12 of the FAO (Food and Agriculture Organization) E-Workshop: Land-water linkages in rural watersheds. 18 September to 27 October 2000. [Online] URL: http://www.fao.org/ag/agl/watershed/

Beach, D. N. 1980. The Shona and Zimbabwe 900-1850. An outline of Shona history. Mambo Press, Gweru, Zimbabwe.

Becker, A., and P. Braun. 1999. Disaggregation, aggregation and spatial scaling in hydrological modelling. Journal of Hydrology 217:239-252.

Beven, K. 1989. Changing ideas in hydrology: the case of physically based models. Journal of Hydrology $\mathbf{1 0 5} 157-172$.

Blackmore, D. J. 1995. Murray-Darling Basin Commission: a case study in integrated catchment management. Water Science and Technology 32: 15-25.

Bloschl, G., and M. Sivapalan. 1995. Scale issues in hydrological modelling: a review. Hydrological Processes 9:251-290.

Bottrall, A. 1992. Institutional aspects of watershed management. Pages 81-90 in Proceedings of the Conference on Priorities for Water Resources Management. July 1992. ODA (Overseas Development Administration), Natural Resources and Engineering, Southampton, UK.

Bromley, J ., J. A. Butterworth, D. M. J. Macdonald, C. J . Lovell, I. Mharapara, and C. H. Batchelor. 1999. Hydrological processes and water resources management in a dryland environment I. An introduction to the Romwe Catchment Study in Southern Zimbabwe. Hydrology and Earth System Sciences 3(3):322-332.

Bugmann, H. 1997. Scaling issues in forest succession modelling. Pages 47-57 in S. J. Hassol and J. Katzenberger, editors. Elements of change 1997 - Session One: Scaling from site-specific observations to global model grids. Aspen Global Change Institute, Aspen, Colorado, USA.

Butterworth, J. A. 1997. The hydrology of a dryland catchment in southern Zimbabwe and the effects of climate and land use change on shallow groundwater resources. Dissertation. University of Reading, Reading, UK.

Butterworth, J. A., R. E. Schulze, L. P. Simmonds, P. Moriarty, and F. Mugabe. 1999. Hydrological processes and water resources management in a dryland environment IV. Long-term groundwater level fluctuations due to variation in rainfall. Hydrology and Earth System Sciences 3(3): 353-361.

Campbell, A., and J. Woodhill. 1999. The policy landscape and prospects of Landcare. Pages 194-208 in F. Hinchcliffe, J. Thompson, J. Pretty, I. Guijt, and P. Shah, editors. Fertile ground: The impacts of participatory watershed management. Intermediate Technology Publications, London, UK.

Campbell, B., J. A. Sayer, P. Frost, S. Vermeulen, M. Ruiz Pèrez, A. Cunningham, and R. Prabhu. 2001. Assessing the performance of natural resource systems. Conservation Ecology 5(2): 22. [Online] URL: http://www.consecol.org/vol5/iss2/art22/

Carney, D., editor. 1998. Sustainable rural livelihoods: what contribution can we make? DFID (Department for International 
Development), London, UK.

Chenje, M., and P. Johnson, editors. 1996. Water in Southern Africa. Southern African Development Community/IUCN/Southern African Research Development Corporation, Maseru/Harare, Zimbabwe.

Clarke, J. 1994. Building on indigenous natural resource management: Forestry practices in Zimbabwe's Communal Lands. Forestry Commission, Harare, Zimbabwe.

Farrington, J., and C. Boyd. 1997. Scaling-up the participatory management of common pool resources. Development policy review 15: $371-391$.

Farrington, J ., and C. Lobo. 1997. Scaling-up participatory catchment development in India: Lessons from the Indo-German Watershed Development Program. ODI Natural Resource Perspectives Number 17. Overseas Development Institute, London, UK.

Feddes, R. A., editor. 1995. Space and time scale variability and interdependenciesin hydrological processes. Cambridge University Press, Cambridge, UK.

Gibbs, C. J. N. 1986. Institutional and organizational concerns in upper watershed management. In K. W. Easter, J. A. Dixon, and M. M Hufschmidt, editors. Watershed resources management: an integrated framework with studies from Asia and the Pacific. Westview Press, Boulder, Colorado, USA.

Gonsalves, J . 2000. Going to scale: can we bring more benefits to more people more quickly? Workshop highlights presented by the CGIAR-NGO Committee and The Global Forum for Agricultural Research with BMZ (German Ministry of Development Corporation), MISEREOR (German Catholic Church Development Agency), Rockefeller Foundation, IRRI (International Rice Research Institute), and IIRR (International Institute of Rural Reconstruction). 10-14 April, IIRR, Philippines.

Harrington, L., J. White, P. Grace, D. Hodson, A. D. Hartkamp, C. Vaughan, and C. Meisner. 2001. Delivering the goods: scaling out results of natural resource management research. Conservation Ecology 5(2): 19. [Online] URL: http://www.consecol.org/ vol5/iss2/art19/

Harvey, L. D. D. 1997. Upscaling in global change research. Pages 14-33 in S. J. Hassol and J. Katzenberger, editors. Elements of change 1997 - Session One: Scaling from site-specific observations to global model grids. Aspen Global Change Institute, Aspen, Colorado, USA.

Hinchcliffe, F., J. Thompson, J. Pretty, I. Guijt, and P. Shah, editors. 1999. Fertile ground: The impacts of participatory watershed management. Intermediate Technology Publications, London, UK.

Holling, C. 1993. Investing in research for sustainability. Ecological Applications 3:552-555.

Jewitt, G. P. W., and A. H. M. Gorgens. 2000. Scale and model interfaces in the context of integrated water resources management for the rivers of the Kruger National Park. Report 627/ 1/ 00. Water Resources Commission, Pretoria, South Africa.

Kalma, J. D., and M. Sivapalan. 1995. i>Scale issues in hydrological/environmental modelling. John Wiley, London, UK.

Kerr, J. M., N. K. Shanghi, and G. Sriramappa. 1996. Subsidies in watershed development projects in India: Distortions and opportunities. Gatekeeper Series Number 61. IIED (International Institute for Environmental Development), London, UK.

Lee, K. 1993. Greed, scale mismatch and learning. Ecological Applications 3:560-564.

Lee, M. 1990. Policy and rule configuration: Korean Rural Development Movement - Saemaul Undong. Presented at the Spring MiniConference, Workshop in Political Theory and Policy Analysis. 28-30 April 1990. Indiana University, Bloomington, Indiana, USA.

Lovell, C. J . 2000. Productive water points in dryland areas: Guidelines on integrated planning for rural water supply. Intermediate Technology Publications, London, UK.

Lovell, C. J ., J . A. Butterworth, P. B. Moriarty, J. Bromley, C. H. Batchelor, I. Mharapara, F. T. Mugabe, G. Mtetwa, T. Dube, and L. Simmonds. 1998. The Romwe Catchment Study, Zimbabwe: The effects of changing rainfall and land use on recharge to crystalline basement aquifers, and the implications for rural water supply and small-scale irrigation. Final Report to DFID (Department for International Development), Report 98/3. Institute of Hydrology, Wallingford, UK.

Makarau, A., and M. R. J ury. 1997. Predictability of Zimbabwe summer rainfall. International J ournal of Climatology b>17: 14211432.

Mandondo, A. 2000. Situating Zimbabwe's natural resource governance systems in history. CIFOR Occasional Paper 32. CIFOR 
(Centre for International Forestry Research), Bogor, Indonesia.

Moriarty, P. B. 2000. Integrated catchment management and sustainable water resource development in semi-arid Zimbabwe, Dissertation. University of Reading, UK.

Moyo, S., D. Robinson, Y. Katerere, S. Stevenson, and D. Gumbo. 1991. Zimbabwe's Environmental Dilemma: Balancing Resource Inequities. Zero, Harare, Zimbabwe.

Murphree, M. W. 2000. Boundaries and borders: the question of scale in the theory and practice of common property management. Paper presented at the Eighth Biennial Conference of the International Association for the Study of Common Property. 31 May to 4 J une 2000. Bloomington, Indiana, USA.

North, D. C. 1990. Institutions, institutional change and economic performance. University of Cambridge Press, Cambridge, UK.

Nemarundwe, N. 2001. Institutional jurisdictions and community-based natural resource management in Chivi District, Zimbabwe: Procedural paper. Dissertation. Uppsala University, Uppsala, Sweden.

NRRD 1998. Research and the sustainable rural livelihoods approach. Pages 131-137 in D. Carney, editor. Sustainable rural livelihoods: What contribution can we make? DFID (Department for International Development), London, UK.

Ostrom, E. 1990. Governing the commons: The evolution of institutions for collective action. Cambridge University Press, Cambridge, UK.

Ostrom, E. 1995. Designing complexity to govern complexity. Pages 33-45 in S. Hanna and M. Munasinghe, editors. Property rights and the environment: social and ecological issues. The Beijer International Institute of Ecological Economics and the World Bank, Washington, D.C., USA.

Peterson, J. H. 1991. CAMPFIRE: A Zimbabwean approach to sustainable development and community empowerment through wildlife utilization. Centre for Applied Social Sciences, University of Zimbabwe, Harare, Zimbabwe.

Ravnborg, H. M., and J. A. Ashby. 1996. Organizing for local-level watershed management: lessons from Rio Cabuyal Watershed, Colombia. AgREN (Agricultural Research and Extension Network, Paper 65. ODI (Overseas Development Institute), London, UK.

Rhoades, R. E. 1998. Participatory watershed research and management: where the shadow falls. Gatekeeper Series Number SA81. International Institute for Environment and Development, London, UK.

Schulze, R. 2000. Transcending scales of space and time in impact studies of climate and climate change on agrohydrological responses. Agriculture, Ecosystems and Environment 82: 185-212.

Schumacher, E. 1973. Small is beautiful: Economics as if people mattered. Bland and Briggs, London, UK.

Shah, P. 1993. Participatory watershed management programs in India: reversing our roles and revising our theories. Pages 38-67 in Rural peoples knowledge: Agricultural research and extension practice. Resource Series 3. IIED (International Institute for Environmental Development), London, UK.

Sposito, G., editor. 1998. Scale dependence and scale invariance in hydrology. Cambridge University Press, Cambridge, UK.

Stewart, J. B., E. T. Engman, R. A. Feddes, and Y. Kerr, editors. 1996. Scaling up in hydrology using remote sensing. John Wiley, Chichester, UK.

Turton, C., and J . Farrington. 1998. Enhancing rural livelihoods through participatory watershed development in India. Natural Resource Perspectives Number 34. ODI (Overseas Development Institute), London, UK.

UNESCO. 1993. Integrated water resource management: Meeting the sustainability challenge. IHP Humid Tropics Programme Series Number 5, UNESCO Press, Paris, France.

van Noordwijk, M., T. P. Tomich, and B. Verbist. 2001. Negotiation support models for integrated natural resource management in tropical forest margins. Conservation Ecology 5(2): 21. [Online] URL: http://www.consecol.org/vol5/iss2/art21

van Zyl, F. C. 1995. Integrated catchment management: is it wishful thinking or can it succeed? Water Science and Technology 32: $27-35$.

Waughray, D. K., C. J . Lovell, E. Mazhangara. 1998. Developing basement aquifers to generate economic benefits: a case study from Zimbabwe. World Development 26(10): 1908-1912. 
Whitlow, J. R., and B. Campbell. 1989. Factors influencing erosion in Zimbabwe: a statistical analysis. J. Environmental Management 29:17-29.

Williams, T. O. 1998. Multiple uses of common pool resources in semi-arid West Africa: a survey of existing practices and options for sustainable resource management. Natural Resource Perspectives Number 38. ODI (Overseas Development Institute), London, UK.

Wood, E. F., and V. Lakshmi. 1993. Scaling water and energy fluxes in climate systems: three land-atmosphere modelling experiments. J ournal of Climate 6:839-857.

\section{Address of Correspondent:}

Chris Lovell

Netherwood Station, RD 6

Blenheim 7321, New Zealand

(formerly at Centre for Ecology and Hydrology

Wallingford, Oxon OX10 8BB, UK)

Phone: +6403572 4044

Fax: +64035724043

c\&c.lovell@xtra.co.nz 